\title{
リンク構造のシミュレーションに関する一考察*
}

\author{
加鳥裕明*1
}

\section{A Note on the Simulation of Linkage Mechanism}

\author{
Hiroaki KATORI*2 \\ ${ }^{* 2}$ Department of Vehicle System Engineering, Meijo University, \\ 1501 Shiogamaguchi, Tempaku ku, Nagoya-shi, Aichi, 468-8502 Japan
}

\begin{abstract}
The dynamic analysis of link structure, including flexible elements is developed in this study. This analysis is based on the finite element method and the direct numerical integration, and can be used to predict the dynamic response of link structures. The purpose of this report is to establish the scheme using FEM for 2-D motional link structures. Some simulation tests are carried out using the scheme and the validity is verified.
\end{abstract}

Key Words : Linkage Mechanism, Finite Element Method, Multi Body Dynamics, Flexible Structure, Computer Aided Analysis

\section{1. 緒言}

近年, メカトロニクス技術の発展により建設機械な どのメカトロ化, ロボット化が進んでいる。ロボット や建設機械などリンク構造を含む機械の設計において は機構部の干涉, 動的強度の検討などが必要であり, さらに,リンク構造の動的挙動を事前に予測すること も重要となっている.ロボットや建設機械など, リン ク構造を含む構造物の動的解析を行うためにマルチボ ディダイナミックスが注目され, 活発な研究が行われ ている. 従来, リンク構造の問題はラグランジュ法な どにより運動方程式を導出し解析されてきた.この手 法では各リンクの情報が他のリンクの情報に依存する こととなる.一方, 有限要素法は局所的関係を示す行 列を組合わせて全体系の行列を構築することからスパ ースな行列が得られる。このような有限要素法の性質 を有効に活用し解析が行われてきている. Uicker(1) は, 閉回路リンク機構の運動を対偶間の座標変換行列 を用いた逐次計算によって数值解析する方法を提案し

* 原稿受付 2004 年5月19 11.

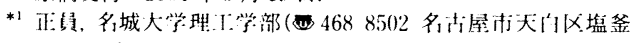
1.1 1.501).

E mail : katori (a ccmfs.meijo) u.ac.jp
ている.さらに, 長松(2) (4) らは,この方法を発展さ せ, 三次元空間において, 閉回路, 開回路および両者 の複合回路への適用を可能にした. 山田ら ${ }^{(5)}$ や村上 $ら^{(6)}$ は, 多数の剛体からなるシステムの運動に関し て, Kane の方法(7)により運動方程式を導き, リアル タイムシミュレーションに適した手法を提案してい る. 近年, より精度の高い解析を行うために構成要素 の柔軟性を考慮した解析が要求されるようになってき た.このような柔軟体を含んだリンク構造の解析に関 する研究として, Sunadaら(8)は, 産業用ロボットに 対して有限要素法による部分構造合成法を用いた手法 を示している.また, 文献 $(9)$ では, 弾性変形と剛体 運動との間の幾何学的非線形性を考慮したモデル化法 について FEM に基づく定式化を示している。ここで 示された絶対節点座標法に注目し，より実用的な定式 化を高橋，清水(10) が提案している.今西(11)らは，柔 軟体が長手方向に移動する場合の振動制御問題を非線 形有限要素を適用して解析する手法を示している.さ らに, 長田 ${ }^{(12)}$ は剛体/柔軟マルチボディ・システムに 適用するぺナルティ法を基礎とする新たな定式化手法 を提案し, 効率良く多自由度の柔軟多体系の並列計算 に適しているシステムの構築を可能にした。 ところで, 有限要素法ははん用性にとむ解析手法と 
して構造解析をはじめさまざまな分野で応用されてい る。構造解析において有限要素法の利用により複雑な 非線形問題も解析が可能となり, 著者も材料および幾 何学的非線形性を考慮した粘塑性大変形解析 ${ }^{(13)(14)}$ を 提案した。機構解析においても静的・動的に部材の変 形特性を考慮する, またより複雑な拘束条件を扱うよ うにするなどを考えるとき, 新たな有限要素法による 計算プログラムを作成することなく, 既存の構造解析 手法に基づく計算プログラムを活用し機構解析が実施 できれば大変有益であると思われる.

そこで本報では, 文献(13)に示される有限要素法に よる構造物の大変形解析手法を利用して, リンク機構 などの運動を解析し, 各部の内力, 速度, 加速度など を求める手法を示す。ここでは, その第一歩としてリ ンク構造を対象として議論する。

\section{2. 理 論}

$2 \cdot 1$ 運動方程式 リンク構造などの運動を解析 するため, 既報で示した大変形解析法を利用する。い ま, ある時刻 $t$ においてダランベールの原理による平 衡状態を考えて, 仮想変位による仮想仕事の原理を適 用すると構造全体に対して, 式（1）が得られる.

$$
\delta \boldsymbol{r}^{T} \boldsymbol{R}=\sum_{i} \delta \boldsymbol{s}^{T} \boldsymbol{S}
$$

ここに, $\boldsymbol{r}$ は節点における一般変位べクトルであり, $\delta \boldsymbol{r}$ は仮想変位を表す， $\boldsymbol{R}$ は一般化変位 $\boldsymbol{r}$ に対応する 節点荷重を表し, 外力と慣性力とからなる。すなわ ち,

$$
\boldsymbol{R}=\boldsymbol{F}-\boldsymbol{M} \dot{\boldsymbol{q}}
$$

ここに, 右辺第 1 項の $\boldsymbol{F}$ は外力および反力であり, 第 2 項は慣性力を表し, $\boldsymbol{M}$ は質量行列, $\boldsymbol{q}$ は節点におけ る速度であり，・は時間微分を表す.

一方, 式(1)の右辺の $\Sigma$ は全要素に対する総和を 表す。また, $\boldsymbol{S}$ は要素の部材力で, これに対応する部 材変形を $\boldsymbol{s}$ と書き表す. $\delta \boldsymbol{s}$ は仮想変位による部材変 形であり, 仮想変位 $\delta \boldsymbol{r}$ との関係を下記のように書き 表すことができる.

$$
\delta \boldsymbol{s}=\boldsymbol{a} \delta \boldsymbol{r}
$$

ここに, $\boldsymbol{a}$ は後述するように座標值を含むマトリック

$\mathrm{x}$

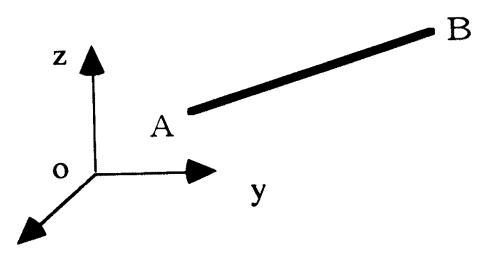

Fig. 1 Three-dimensional Truss element
スである。

以上の 3 式より節点の運動方程式が下記のように得 られる。

$$
\boldsymbol{M} \dot{\boldsymbol{q}}=\boldsymbol{F}-\sum_{i} \boldsymbol{a}^{T} \boldsymbol{S}
$$

$2 \cdot 2$ 部材の構成方程式本報では, 簡単のため トラス構造に限ることとする。眓 1 に示すように, 右 手直交座標系 $\boldsymbol{x}(x, y, z)$ を全体座標系として, ある時 刻 $t$ における部材両端 $\mathrm{A}, \mathrm{B}$ の座標をそれぞれ $\boldsymbol{x}_{A}$, $x_{B}$ とすると部材変形 $\dot{s}$ は $l=\sqrt{\left(x_{B}-x_{A}\right)^{T}\left(x_{B}-x_{A}\right)}$ より次のように得られる。

$$
\begin{aligned}
\dot{\boldsymbol{s}} & =\Delta i=\left(\frac{x_{B}-\boldsymbol{x}_{A}}{l}\right)^{T}\left(\dot{\boldsymbol{x}}_{B}-\dot{\boldsymbol{x}}_{A}\right) \\
& =\left(\begin{array}{ll}
-\lambda^{T} & \lambda
\end{array}\right)\left(\begin{array}{l}
\boldsymbol{q}_{A} \\
\boldsymbol{q}_{B}
\end{array}\right)=\boldsymbol{a} \boldsymbol{q} \ldots \ldots \ldots \ldots
\end{aligned}
$$

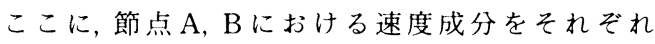
$\dot{\boldsymbol{x}}_{A}=\boldsymbol{q}_{A}, \dot{\boldsymbol{x}}_{B}=\boldsymbol{q}_{B}$ と表し,$\lambda=\left(\boldsymbol{x}_{B}-\boldsymbol{x}_{A}\right) / l$ は部材軸 $\mathrm{AB}$ を $x^{\prime}$, これに垂值に断面主軸方向を $y^{\prime}, z^{\prime}$ とする 局所座標系の全体座標系 $x(x, y, z)$ に対する方向余弦 を表す。また，先に述べたように式（5)0ａは，両節 点 $\mathrm{A}, \mathrm{B}$ の座標值 $x_{A}, x_{B}$ によって書き表される.

この部材変形の時間增分 $\dot{s}$ に対応する部材力の時 間増分を $\dot{\boldsymbol{S}}$ とすると弾性棒における構成式は剛性行 列を用いて示すことができる.また，ダンパが部材と して含まれる場合, 減衰力が線形減衰として表される とすると, 減衰力は減衰行列を用いて示すことができ る.すなわち,

$$
\left.\begin{array}{l}
\text { 弾性棒の場合 }: \dot{\boldsymbol{S}}=\boldsymbol{k} \dot{\boldsymbol{s}}=\boldsymbol{k a q} \\
\text { ダンパの場合 }: \boldsymbol{S}=\boldsymbol{c} \dot{\boldsymbol{s}}=\boldsymbol{c a q} \\
\text { トラス部材の場命 }: \boldsymbol{k}=E A / l
\end{array}\right\}
$$

ここに, $\boldsymbol{k}$ は剛性行列, $\boldsymbol{c}$ は減衰䘕列を表す。なお, $E$ はヤング率, $A$ は断面積, lは部材長を表す。

\section{$2 \cdot 3$ 運動方程式の直接積分 前述の $2 \cdot 1$ 節で示} された式（4）の運動力程式の有辺第 2 項に式（6)で示 された弾性棒とダンパに関する構成方程式をそれぞれ 区別して書き淔すと次のように表される。

$$
\left.\begin{array}{l}
M \dot{q}=F-\sum_{i} a^{T} S-\sum_{i} \alpha^{\prime} c^{\prime} a^{\prime} q \\
\dot{S}=k a q, \quad S^{\prime}=c a^{\prime} q, \quad \dot{r}=q
\end{array}\right\}
$$

ここに, 式 (7-1)の有辺第2 項，第3 項はそれぞれ弾性 棒に関する総和とダンパに関する総和を示し,ダンパ に関する部材力および節点変隹との関係を表す行列 $\boldsymbol{a}$ にそれぞれ( )'を付けて書き表し、ダンパにおける部

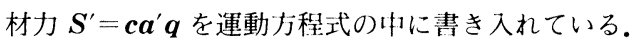

式(7)を基に, 時刻 $t=t_{0}$ における $\boldsymbol{r}_{0}, \boldsymbol{q}_{0}, S_{0}$ を既 知として, 時刻 $t=t_{1}=t_{0}+\Delta t$ に打ける $\boldsymbol{r}_{1}, \boldsymbol{q}_{1}, \boldsymbol{S}_{1}$ を 直接数值積分によって求めることを考える。值接数値 
積分法にはさまざまな方法があるが, Runge-KuttaGill 法は精度に優れているが, 高周波成分に対して不 安定という欠点があり, Newmark の $\beta$ 法 $(\beta=1 / 4)$ は精度は不十分であるが無条件安定性と簡便さにおい て優れて, 刻み時間を Runge-Kutta-Gill 法の場合の $1 / 3$ 程度にとれば精度も同程度となり計算労力も小さ いことが文献(14)に示されている。このことから，こ こではNewmark の $\beta$ 法 $(\beta=1 / 4)$ を用いることとす る.

いま, 式( 7 )を時刻 $t_{0} お よ ひ ゙ t_{1}$ において書き值す とそれぞれ次のように書き表される。すなおち, 時刻 $t_{0}$ において

$$
\left.\begin{array}{l}
\boldsymbol{M} \dot{\boldsymbol{q}}_{0}=\boldsymbol{F}_{\mathbf{0}}-\sum_{i} \boldsymbol{a}_{0}{ }^{T} \boldsymbol{S}_{0}-\sum_{i} \boldsymbol{a}_{0}{ }^{T} \boldsymbol{c} \boldsymbol{a}_{0}{ }^{\prime} \boldsymbol{q}_{0} \\
\dot{\boldsymbol{S}}_{0}=\boldsymbol{k} \boldsymbol{a}_{0} \boldsymbol{q}_{0}
\end{array}\right\}
$$

時刻 $t_{1}$ において

$$
\left.\begin{array}{l}
\boldsymbol{M} \dot{\boldsymbol{q}}_{1}=\boldsymbol{F}_{1}-\sum_{i} \boldsymbol{a}_{1}{ }^{T} \boldsymbol{S}_{1}-\sum_{i} \boldsymbol{a}_{1}^{\prime T} \boldsymbol{c} \boldsymbol{a}_{1}^{\prime} \boldsymbol{q}_{1} \\
\dot{\boldsymbol{S}}_{1}=\boldsymbol{k} \boldsymbol{a}_{1} \boldsymbol{q}_{1}
\end{array}\right\}
$$

ここに示した式の中， $\boldsymbol{a}_{0} ， \boldsymbol{a}_{1}$ などには式(5)からわか るようにその時刻における座標値を含むこととなる が, 増分は微小であることから, $\boldsymbol{a}=\boldsymbol{a}_{0}=\boldsymbol{a}_{1}$ および $\boldsymbol{a}^{\prime}=\boldsymbol{a}_{0}^{\prime}=\boldsymbol{a}_{1}^{\prime}$ として計算を簡単にする。このような簡 単化による解析結果が実用上十分な精度の解が得られ るのであれば, 有限要素法を用いたリンク構造の運動 解析の定式化や演算は極めて単純となり, 少ない計算 労力で解析が実行できることとなる. また, 質量行列 は集中質量系として解析を行う.なお,より精密に解 析するため $\boldsymbol{a}_{0}, \boldsymbol{a}_{1}$ の差を取り入れるには, 幾何剛性 行列を用いることとなる.

Newmark の $\beta$ 法 $(\beta=1 / 4)$ において, $\boldsymbol{q}_{1}$ などは次 のように表される.

Table 1 Parameter of the analysis

\begin{tabular}{lcc}
\hline & CASE-1 & CASE-2 \\
\hline Length $\ell_{1}(\mathrm{~m})$ & \multicolumn{2}{c}{0.2} \\
Length $\ell_{2}(\mathrm{~m})$ & \multicolumn{2}{c}{0.35} \\
Density $\left(\mathrm{kg} / \mathrm{m}^{3}\right)$ & \multicolumn{2}{c}{2700} \\
Axial Rigidity of Rods $(\mathrm{N})$ & $7 \times 10^{6}$ & $7 \times 10^{5}$ \\
\hline
\end{tabular}

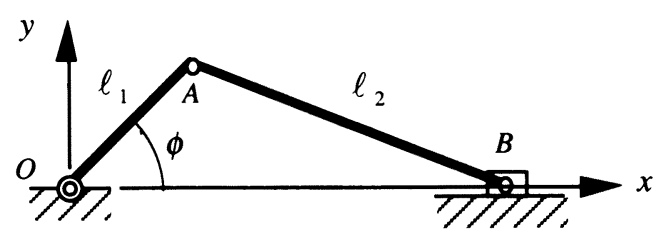

Fig. 2 Slider-crank linkage

$$
\left.\begin{array}{l}
\boldsymbol{q}_{1}=\boldsymbol{q}_{0}+\frac{\Delta t}{2}\left(\dot{\boldsymbol{q}}_{1}+\dot{\boldsymbol{q}}_{0}\right) \\
\boldsymbol{S}_{1}=\boldsymbol{S}_{0}+\frac{\Delta t}{2}\left(\dot{\boldsymbol{S}}_{1}+\dot{\boldsymbol{S}}_{0}\right)
\end{array}\right\}
$$

式(10-1)に質量行列を掛け得られた式の右辺に式 （8)，（9)，(10-2)を代入し整理すると式(11)が得ら れる。

$$
\begin{aligned}
&(\boldsymbol{M}\left.+\frac{\Delta t}{2} \boldsymbol{C}+\frac{\Delta t^{2}}{4} \boldsymbol{K}\right)\left(\boldsymbol{q}_{1}+\boldsymbol{q}_{0}\right) \\
&=2 \boldsymbol{M} \boldsymbol{q}_{0}+\frac{\Delta t}{2}\left(\boldsymbol{F}_{1}+\boldsymbol{F}_{0}\right)-\Delta t \sum_{i} \boldsymbol{a}^{T} \boldsymbol{S}_{0}
\end{aligned}
$$

ここに,

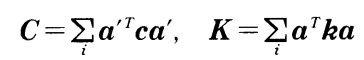

であり, $\boldsymbol{C}$ は減衰行列, $\boldsymbol{K}$ は剛性行列である.

式(11)を解いて $\boldsymbol{q}_{1}+\boldsymbol{q}_{0}$ が求められると， $\boldsymbol{q}_{0}$ は既知 であることから $\boldsymbol{q}_{1}$ が得られることとなり, 式(8-2), (9-2)，(10-2)より $S_{1}$ が求められる.また,

$$
\boldsymbol{r}_{1}=\boldsymbol{r}_{0}+\frac{\Delta t}{2}\left(\boldsymbol{q}_{1}+\boldsymbol{q}_{0}\right)
$$

より $\boldsymbol{r}_{1}$ が得られる.いま, 得られた $\boldsymbol{r}_{1}, \boldsymbol{q}_{1}, \boldsymbol{S}_{1}$ を $\boldsymbol{r}_{0}$, $q_{0}, S_{0}$ に置換えてこれまでの手順を繰返すという形 で計算を進めていくことができる.

\section{3. 数 值 計 算 例}

ここでは, 2 章で示した手法の精度, 有効性を検討 するため, いくつかの問題について解析を行った.

$3 \cdot 1$ スライダ・クランク機構 最初に図 2 に示 すようなスライダ・クランク機構について解析を行っ た.この機構の構成要素の諸元を表 1 に示す.ここで は, コネクティングロッド $\mathrm{AB}$ の軸剛性 $\mathrm{EA}$ が十分高 い場合 (剛体 : CASE-1) と低い場合(柔軟体: CASE2)の二つのケースについて計算を行った. シミュレー ションで行う積分の時間刻みは 0.0005 秒とした。最 初にCASE-1 の剛性を持つリンク機構のクランクを 一定の角速度 $\omega=0.2 \pi \mathrm{rad} / \mathrm{s}$ で回転すなわち 10 秒で 1 回転とゆっくりな運動について計算を行った. 図 3(a) はこの機構の挙動図を示し, 図 3(b), (c) は点 $\mathrm{B}$ の位置 $(x)$ およびコネクティングロッドの軸力 $(S)$ の時刻歴応答図を示す. 図 3(b)の中には, 式(14)で 与えられる点 $\mathrm{B}$ の位置に関する解析結果も点線で示 してあるが, 本解析結果はその解析結果と重なってお り,よい一致を示している.

$$
x=l_{1} \cos \omega t+l_{2} \sqrt{1-\left(l_{1} / l_{2}\right)^{2} \sin ^{2} \omega t}
$$

次に柔軟体の要素を有する CASE-2 のリング構造 において, 点 B に集中質量 $5 \mathrm{~kg}$ が付加されクランク が一定の角速度 $\omega=2 \pi \mathrm{rad} / \mathrm{s}$ で回転すなおち 1 秒で 1 回転する運動について計算を行った，図 4 にその結果 
を示す.図 4(a) は機構の挙動図, 図 4(b) および ( c ) はスライダ(点 B) の位置およびコネクティングロ ッドの軸力の時刻歴応答をそれぞれ示している. 図 4 ( a )では, コネクティングロッドの剛性が小さいこ とからコネクティングロッドが弾性大変形しながらス ライダが直線運動していくようすがわかる．また，図 4 ( b ) には CASE-1 で示す軸剛性を持つ場合の計算結 果も示してあるが, 図 4 (b)，（c）には機構を構成す る要素として柔軟体を有することや集中質量の慣性力 の影響により点 $\mathrm{B}$ (スライダ)の応答および部材に生じ る軸力の時刻歴応答に位相差が現れているようすが示 されている.

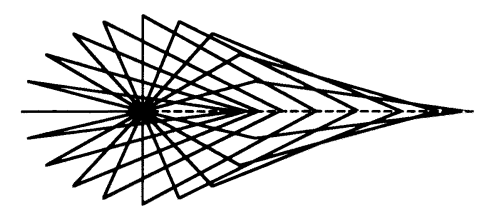

(a) Animation

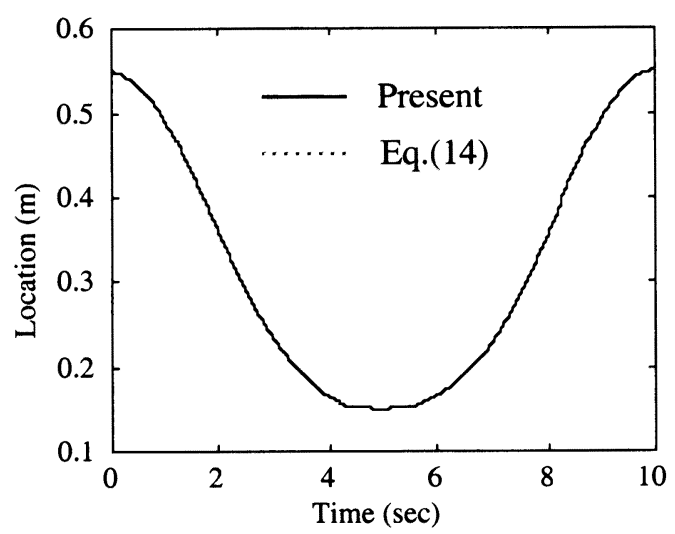

(b) Location of the slider

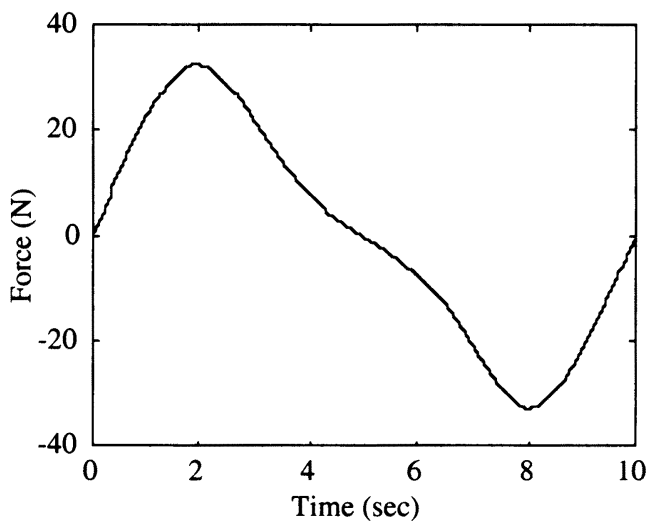

(c) Axial force of the connecting rod

Fig. 3 Slider-crank linkage (CASE-1)
次に, 図 5 には, CASE-2 に打いて角速度 $\omega=4 \pi$ $\mathrm{rad} / \mathrm{s}$ としたときの解析結果を示す.図 5(a)には点 $\mathrm{B}$ (スライダ)の位置の時刻歴応答を, 図 5(b)にはコ ネクティングロッドの軸力の時刻歴応答を示す.図 5(a)の中にはCASE-10場合の結果も示している. これらの結果から, 角速度が増したことによりスライ ダは, その移動量が減少し，コネクティングロッドに は最大值で $47 \%$ 大な軸力が生じていることがわかる.

$3 \cdot 2$ 平面 4 節機構 次にさまざまなシステムに 使用される基本的機構の一つである図 6 に示す平面 4 節機構について解析を行った。この機構の構成要素の 緒元を表 2 に示す。ここでは，角速度 $\omega=2 \pi \mathrm{rad} / \mathrm{s}$ お

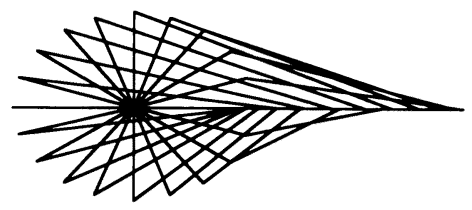

(a) Animation

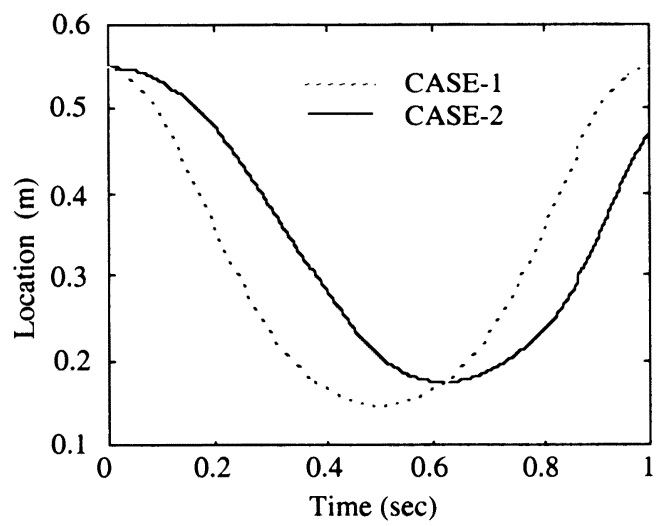

(b) Location of the slider

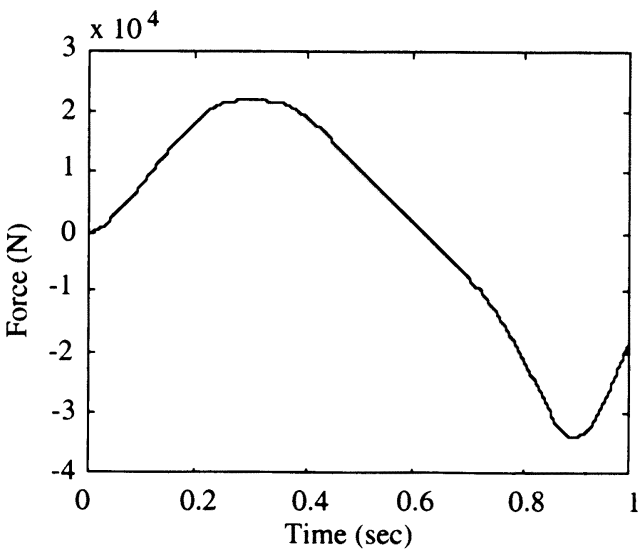

(c) Axial force of the connecting rod

Fig. 4 Slider crank linkage (CASE 2, $\omega=2 \pi \mathrm{rad} / \mathrm{s}$ ) 
よび $40 \pi \mathrm{rad} / \mathrm{s}$ で入力節 $\mathrm{O}_{2} \mathrm{~A}$ が回転する場合につい て計算を行った。 $\omega=2 \pi \mathrm{rad} / \mathrm{s}$ で回転させた場合の挙 動図を図 7(a)に示し, 入力角 $(\theta)$ と出力角 $(\phi)$ の関 係を図7(b)にそれぞれ示す. 図7(b)の中には式 (15)で与えられる入力角と出力角の解析結果も点線で 示されているが, 本解析結果はその解析結果と重なっ ており,よい一致を示している.

$$
\begin{aligned}
\phi & =\tan ^{-1}\left[\frac{l_{2} \sin \theta}{l_{1}+l_{2} \cos \theta}\right] \\
& +\cos ^{-1}\left[\frac{l^{2}+l_{4}{ }^{2}-l_{3}{ }^{2}}{2 l_{4}}\right]
\end{aligned}
$$

Table 2 Parameter of the analysis (four bar linkage)

\begin{tabular}{|l|c|}
\hline Length $\ell_{1}, \ell_{3}, \ell_{4}(\mathrm{~m})$ & 0.3 \\
Length $\ell_{2}(\mathrm{~m})$ & 0.2 \\
Density $\left(\mathrm{kg} / \mathrm{m}^{3}\right)$ & 2700 \\
Axial Rigidity of Rods $(\mathrm{N})$ & $7 \times 10^{6}$ \\
\hline
\end{tabular}

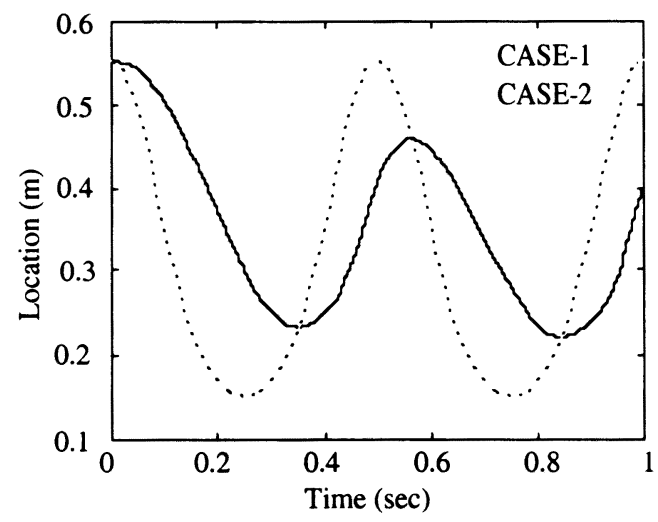

(a) Location of the slider

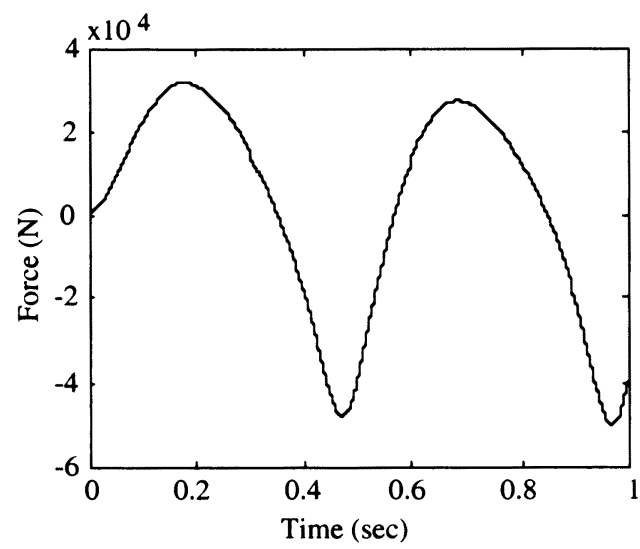

(b) Axial force of the connecting rod

Fig. 5 Slider crank linkage (CASE 2, $\omega=4 \pi \mathrm{rad} / \mathrm{s}$ )
ここに, $l^{2}=l_{1}^{2}+l_{2}^{2}+2 l_{1} l_{2} \cos \theta$.

次に $\omega=40 \pi \mathrm{rad} / \mathrm{s}$ の場合の挙動図と入出力角の関係 図を図 8(a)，（b）にそれぞれ示す。角速度が増した ことで慣性力の影響により中間節が変形し, 入力角が 約 2.6〜 $4 \mathrm{rad}\left(\right.$ 約 $150 \sim 230^{\circ}$ )の範囲において出力角が 剛体として計算される式(15) とは若干ではあるが差を 生じることがわかる.

図 9 には中間節 $\mathrm{AB}$ の中央点 $\mathrm{C}$ の $x y$ 平面での軌跡

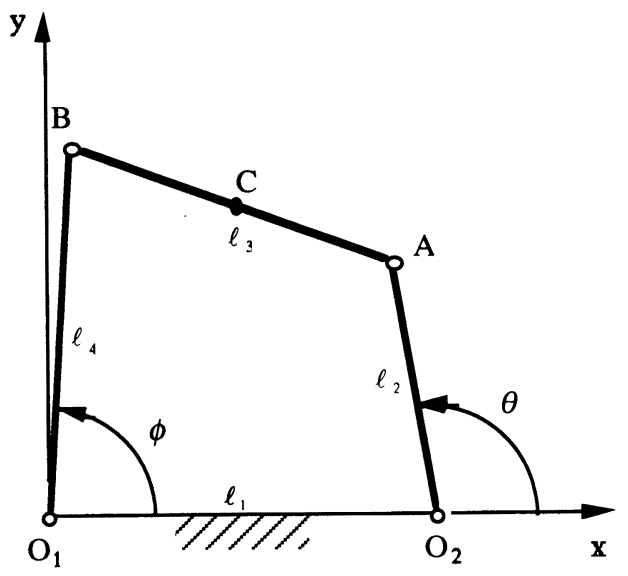

Fig. 6 Four-bar linkage

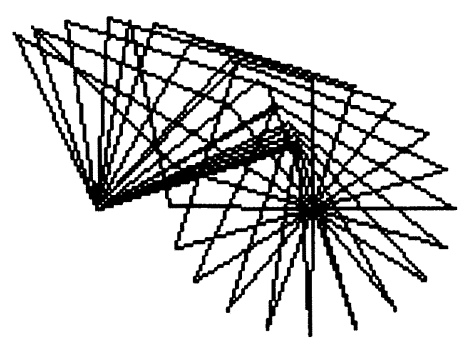

(a) Animation

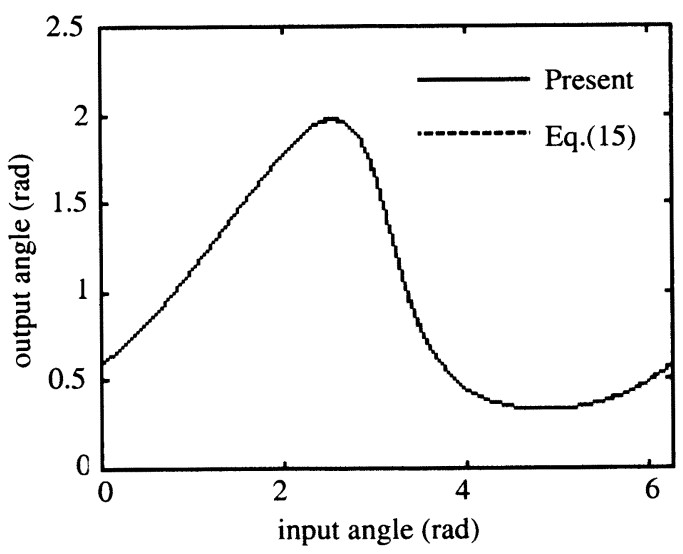

(b) Input angle vs. output angle

Fig. 7 Four-bar linkage $(\omega=2 \pi \mathrm{rad} / \mathrm{s})$ 
を示す．上述の出力角に差を生じる範囲において軌跡 にも差が生じているようすが示されている.

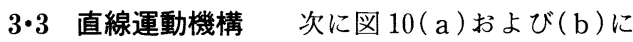
示すような直線運動機構としてよく知られたポースリ エの機構を CASE-1 として,さらにダンパと部材が 取付けられた機構をCASE-2 として解析を行い, ダ ンパが含まるれ場合の解析の有効性を確認した，最初 にCASE-1の場合において部材 $\mathrm{O}_{2} \mathrm{~A}$ を $\omega=0.2 \pi$

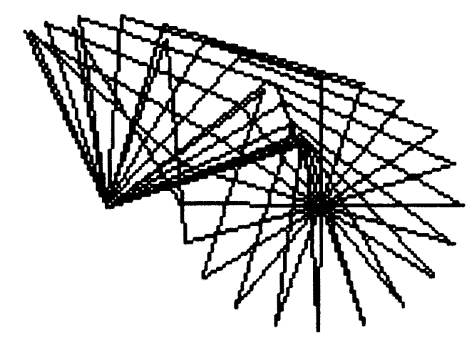

(a) Animation

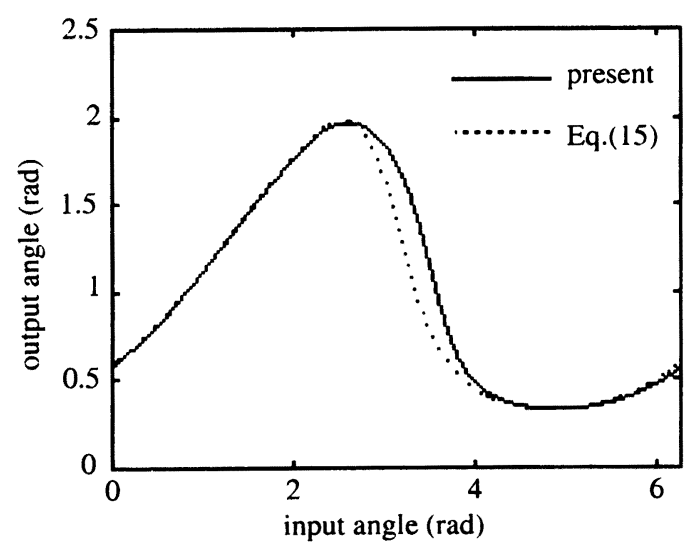

(b) Input angle vs. output angle

Fig. 8 Four-bar linkage $(\omega=40 \pi \mathrm{rad} / \mathrm{s})$

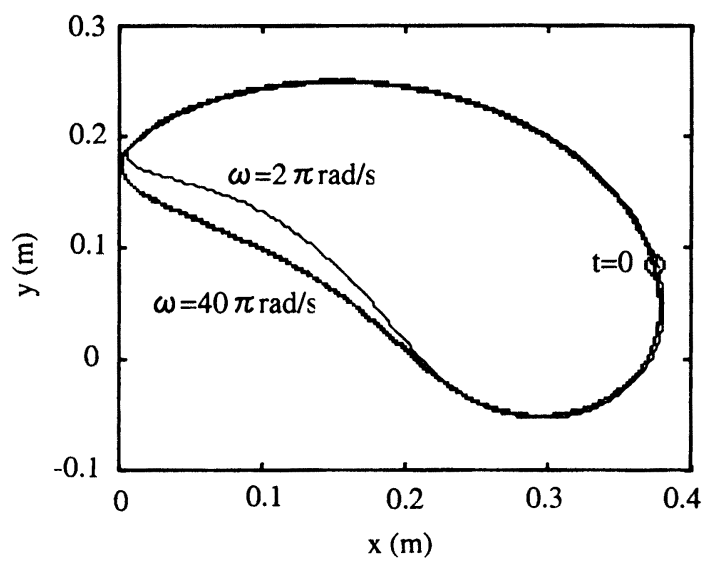

Fig. 9 Locus of point $\mathrm{C}$

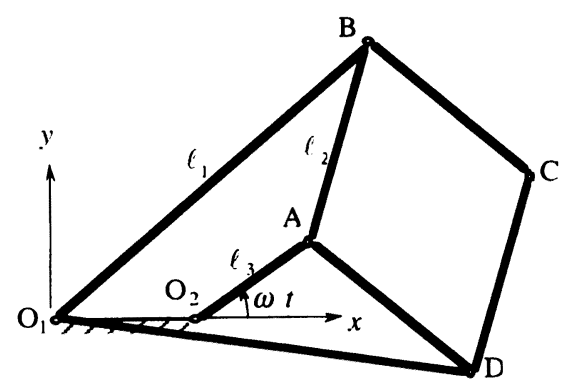

(a) CASE 1

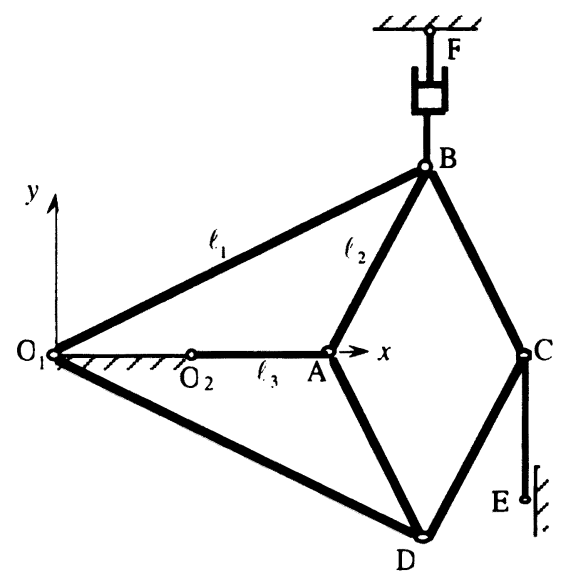

(b) CASE 2

Fig. 10 Peaucellier's linkage

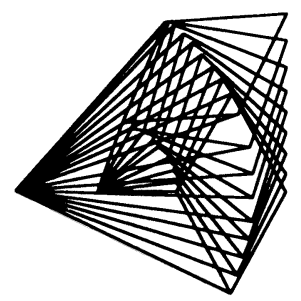

(a) Animation

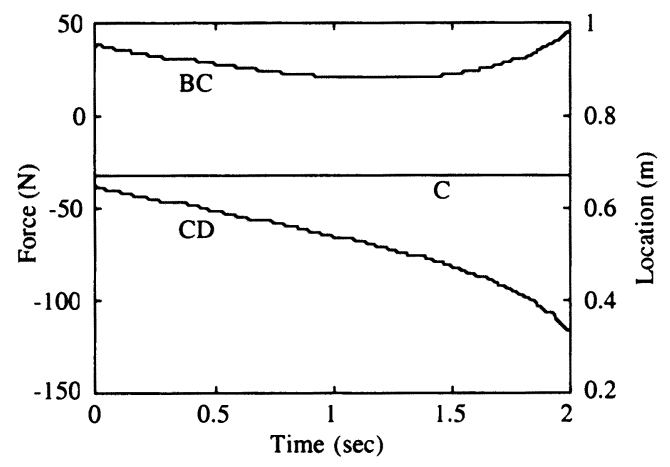

(b) Axial force and location

Fig. 11 Peaucellier's linkage (CASE-1, $\omega=0.2 \pi \mathrm{rad} / \mathrm{s}$ ) 


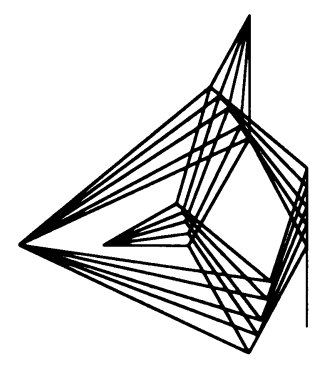

(a) Animation

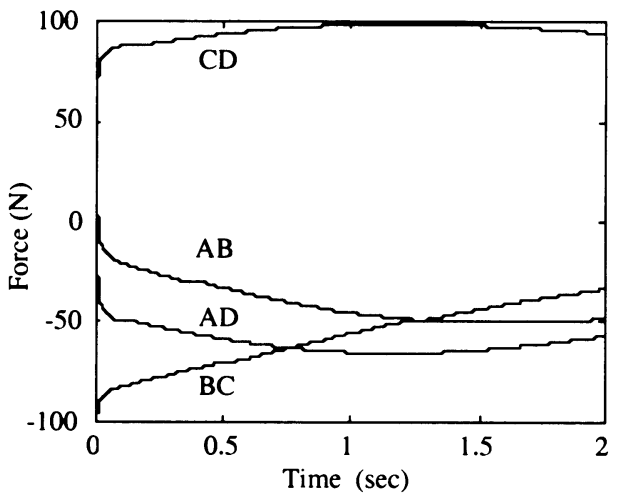

(b) Axial force

Fig. 12 Peaucellier's linkage (CASE $2, v_{E y}=0.1 \mathrm{~m} / \mathrm{s}$ )

$\mathrm{rad} / \mathrm{s}$ の角速度で $\mathrm{O}_{1}$ 点まわりに 2 秒回転させた場合 について計算を行った。計算に用いた構成要素の軸剛 性や質量は $3 \cdot 1$ 節で示した解析例 CASE-1 で用いた 値を使用した。なお，各部材の長さは $l_{1}=0.6 \mathrm{~m}, l_{2}=$ $0.3 \mathrm{~m}, l_{3}=0.2 \mathrm{~m}$ とした。この解析結果を図 11 に示 す.図11(a)はこの機構の挙動図であり, 図11(b) は点 $\mathrm{C}$ の $x$ 座標値と部材 $\mathrm{BC}, \mathrm{CD}$ の軸力の時刻歴応 答図である。これらの結果において点 $\mathrm{C}$ が直線上を 移動することが示されており，妥当な結果が得られて いる.また，点 Cが直線運動できる幾何学的限界に近 づくと軸力の絶対値が大きくなることが示されてい る. 次に, CASE-2 の場合において点 Cに集中質量 5 $\mathrm{kg}$ を取付け, 点 $\mathrm{E}$ を速度 $0.1 \mathrm{~m} / \mathrm{s}$ で鉛直上方に動か したときの機構の挙動を解析した。その結果を図 12 に示す.図 $12(\mathrm{a})$ にはこの機構の挙動図を示し, 図
12 ( b ) には各部材の軸力の時刻歷応答図を示す．点 B の動きがダンパにより拘束されることから，各部材に 大きな軸力が生じることがわかる。

\section{4. 結 論}

本研究では柔軟体やダンパを含むりンク機構を対象 として, 有限要素法による構造物の大変形解析手法を 利用して,リンク機構の運動解析を行い, 各部材の内 力, 速度, 加速度などを求める手法を示した。いくつ かのシミュレーションの結果, 本手法は比較的低速な 場合の結果のみではあるが, 2 種類の基本的なリンク 機構の運動に対して実用上十分な精度で解析できるこ とが確認できた。 また, 本手法は, 三次元リンク機構 や二次元においてもより複雑なりンク機構に対しても 応用が可能であると考えられる.今後は，はり要素な ど他の構成要素を含むシステムについても解析できる

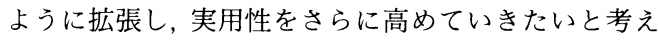
ている.

\section{文献}

(1) Uicker, J. J. Jr., Denavit, J. and Hartenberg, R. S., Trans. ASME, Ser. E, 31 (1964), 309.

（2）長松昭男・斉藤俊・一柳高畤, 機論, 51-470, C (1985), 2668-2676.

（3）長松昭男・斉藤俊・一柳高時, 機論, 51 -470, C (1985), 2677-2683.

（4）長松昭男・斉藤俊・桜井康雄, 機論, 51-470, C (1985), 2684-2689.

（5）山田克彦 -土屋和雄, 機論, 53-491, C (1987), 1598-1605.

(6) 村上晃 - 加藤寛一郎, 日本航空宇宙学会誌，39-444 (1991), 39-43.

( 7 ) Kane, T. R. and Levinson, D. A., J. Appl. Mech., 50 (1983), 1071-1078.

(8) Sunada, W. H. and Dubowsky, S., Trans. ASME, J. Mech. Trans. Autom. Des., 105 (1983), 42-51.

(9) Shabana, A. A., Hussien, H. A. and Escalona, J. L., Trans. ASME, J. Mech. Des., 120 (1998), 188-195.

（10）高橋義考 - 清水信行, 機論, 67-655, C (2001), 626-632.

(11) Imanishi, E. and Sugano, N., JSME Int. J., Ser. C, 46 2 (2003), 527-532.

(12) Nagata, T., JSME Int. J., Ser. C, 46-2 (2003), 459-466.

（13）村瀬勝彦 - 加鳥裕明 - 西村融, 機論, 48-434, A (1982), $1318-1324$.

（14）村瀬勝彦 - 加鳥裕明 - 西村融, 機論, 49-438, A (1983), 223-229. 